\title{
CRISIS, RESCUE, AND CORPORATE SOCIAL RESPONSIBILITY UNDER AMERICAN CORPORATE LAW
}

\author{
Robert J. Rhee ${ }^{\dagger}$
}

This chapter discusses the legal issues of corporate governance raised by the unique events surrounding the Bank of America-Merrill Lynch merger in the fourth quarter of 2008. It is substantially based on the author's previous article on a corporate board's fiduciary duty related to the management of a public crisis and the provision of aid to government and the public. ${ }^{1}$ The thesis is that American corporate law adequately provides corporate boards authority to assume broad principles of corporate social responsibility, and that during a public crisis this authority is specially recognized in the enabling statutes of corporate law and should be broadened even further to pursue the public good in exigent circumstances. No situation calls from a greater sensitivity to corporate social responsibility than during a crisis when great detriment to the social wealth and welfare are at stake.

Since the financial crisis of 2008-2009 and the financial industry provide the context for the discussion here, a little background is in order. In the past twenty years, the investment banking industry underwent a fundamental transformation. Before the 1999 repeal of the Glass-Steagall Act, which had separated commercial and investment banking, investment banks merged among themselves, and after the regulatory wall came down investment banks were acquired by larger commercial banks. By 2007, there were only five independent pure investment banks of significant size and operational scale: Goldman Sachs, Morgan Stanley, Merrill Lynch, Lehman Brothers, and Bear Stearns. Their activities in the post-9/11 years precipitated the financial crisis of 2008-2009. In 2008, the unthinkable happened: three of the five banks collapsed or were sold under duress. In March, Bear Stearns became insolvent and it was rescued by JPMorgan Chase and the federal government. In September, Lehman Brothers filed for bankruptcy on the same day that Bank of America announced the acquisition of an increasingly troubled Merrill Lynch. The fall of three major investment banks, the bulk of old Wall Street, within a few months confirmed a systemic crisis.

${ }^{\dagger}$ Professor of Law \& Co-Director of the Business Law Programme, University of Maryland School of Law.

${ }^{1}$ Rhee, R.J. (2010), 'Fiduciary Exemption for Public Necessity: Shareholder Profit, Public Good, and the Hobson's Choice during a National Crisis', George Mason Law Review, Vol. 17, pp. 661736. 
The events unique to the Bank of America-Merrill Lynch merger, which gave rise to the author's contemplation of these issues, are briefly summarized. As the financial crisis was deepening in the fourth quarter of 2008, Merrill Lynch was losing money at an astonishing rate (ultimately $\$ 15$ billion in fourth quarter). This prompted Bank of America to consider terminating the pending merger under the merger agreement's material adverse change clause. The deal ultimately closed, but only after the government threatened to fire Bank of America's management and board if the company attempted to terminate the deal. The government feared that a broken deal would continue a domino effect on other financial institutions resulting in a systemic financial market meltdown. In fact, Bank of America did not have a contractual right to terminate the merger. As defined in the merger agreement, material adverse change did not encompass Merrill Lynch's astonishing losses. The government was correct to coerce a reluctant Bank of America management and board to do the right thing. However, suppose hypothetically Bank of America had a sound contractual right to terminate the merger, thereby cutting Merrill Lynch loose for the sake of avoiding the assumption of its losses. All would agree that a broken deal would have resulted in the collapse of Merrill Lynch as an independent firm, which would have exacerbated the financial crisis with unknown consequences on other financial institutions, the capital markets, and the greater society. Consider, then, the counterfactual: Bank of America had a legally viable option to terminate the merger and the cost-benefit based on private gain or loss to the firm weighed in favor of termination.

This history and counterfactual contextualize an analysis of important, unresolved theoretical issues at the intersection of corporate governance and public crisis management:

1. What is the nature and scope of its fiduciary duty under American corporate law during a public crisis?

2. Should the board have specific authority and discretion to advance the public welfare at the direct cost of the shareholder wealth?

There will always be public crises that entangle the government and corporations in a complex relationship. These questions continue the longstanding academic debate on the purpose of the corporation and the manager's duty to stakeholders. ${ }^{2}$

${ }^{2}$ See, e.g., Berle, A.A. (1931), 'Corporate Powers as Powers in Trust', Harvard Law Review, Vol. 44, pp. 1049-1074; E. Merrick Dodd, E.M. (1032), 'For Whom Are Corporate Managers Trustees?', Harvard Law Review, Vol. 45, pp. 1145-1163. 
Since this book is published in the UK and will reach a broad international audience, a brief explanation of the US corporate law system is required. The reference to 'American corporate law' is a misnomer to the extent that it connotes a single body of law. In the US, corporate law is the set of rules governing the internal affairs and management of the corporation. It is not unified under federal law, but is primarily based on individual state law. The Delaware General Corporation Law ('DGCL') and the judicial opinions of the Delaware courts are prominent. In addition to Delaware law, many other states have substantially adopted the Model Business Corporation Act (the 'Model Act'), an influential model statute prepared by a committee of the American Bar Association. American corporate law is thus composed of many sets of corporate law. However, Delaware law can be seen as a quasi-national body of corporate law simply because so many public companies are incorporated in Delaware. For this reason, this chapter focuses on Delaware law.

This chapter discusses the board's fiduciary obligation during a public crisis. Even without a grant of power specific to the management of a public crisis, corporate boards have broad power as managers of the corporation to incorporate principles of corporate social responsibility in the pursuit of business enterprise, and such decisions are protected by the business judgment rule. As a positive thesis, this chapter shows that the board has the specific power to nationalize corporate purpose per public necessity, which is authorized by section 122(12) of the DGCL and section 3.02(14) of the Model Act. As a normative thesis, this chapter argues that these statutes provide a framework for courts to recognize a fiduciary exemption based on the board's determination that the firm, being uniquely situated to avert or mitigate the public crisis, should provide aid. Public necessity, a well established concept in Anglo-American tort law, excuses the destruction of private property. When the board perceives that the threat to the public welfare is great enough, the shareholder primacy norm can and sometimes does fail the stress test of a crisis. The thesis depends on a fundamental assumption, which is explicitly stated: the situation examined here is where a corporation is uniquely situated to avert or mitigate a public crisis at a substantial private cost to the firm, but where the cost-benefit calculation from a societal perspective overwhelmingly weighs in favor of such action. This is the nature of a public necessity.

\section{CORPORATE SOCIAL RESPONSIBILITY AND BUSINESS JUDGMENT}

When a board is faced with a choice of aiding the public or government during a crisis, or more generally any corporate social responsibility initiative, well established doctrines of American corporate law can protect directors from legal liability in a shareholder derivative lawsuit. A hallmark trait of the public 
corporation is a separation of ownership and control. ${ }^{3}$ Accordingly, managers have great authority over corporate assets. Delaware corporate law provides that ' $\mathrm{t}]$ he business and affairs of every corporation organized under this chapter shall be managed by or under the direction of a board of directors. ${ }^{4}$ The board has the authority to manage the 'business and affairs' of the corporation, which in the judgment of the board may include corporate social responsibility initiatives and decisions based thereon.

To serve the end of manager prerogative, American courts have developed the business judgment rule, which gives great deference to the business decisions of managers. The rule is a rebuttable presumption that in making a business decision the board acted on an informed basis, in good faith and in the honest belief that the action taken was in the best interests of the company. ${ }^{5}$ The rule applies when four conditions are met: (1) a judgment must have been made; (2) a reasonable decision making process was used; (3) the decisions must have been made in subjective good faith; (4) the decision was not tainted by self-interest. The conditions boil down to two questions: Did the board reach its decision in good faith pursuant to a legitimate corporate interest? Did the board do so advisedly? ${ }^{6}$ The first question concerns the loyalty of directors to the best interest of the corporation; the second question concerns a reasonable use of procedure in making a decision.

The business judgment rule is a presumption operating in favor of the propriety of the board's intent and decision, and an objecting shareholder must rebut the presumption of good faith and reasonable process with particular facts demonstrating the contrary. If a board decides to aid the public or government during a public crisis, the most important point is that it must do so advisedly. It must use a reasonable decision-making process characterized by adequate information gathering and deliberation. When the procedural requirement of the business judgment rule has been met, courts will only review the decision under the waste standard, which is met when the board's decision is so disadvantageous to the firm that no reasonable person could deem it fair. ${ }^{7}$

Even when a board decision appears to injure the corporation, courts avoid active scrutiny of the decision's merit by invoking the elision that a board's

\footnotetext{
3 Berle, A.A. and Means, G.C. (1932), The Modern Corporation and Private Property, Transaction Publishers, New Jersey.

${ }^{4}$ Del. Code Ann. tit. $8 \S 141$ (a). See Mod. Bus. Corp. Act $\S 8.01(b)$ (1984).

${ }^{5}$ Aronson v. Lewis , 473 A.2d 805, 812 (Del. 1984).

${ }^{6}$ Gantler v. Stephens, 965 A.2d 695, 706 (Del. 2009).

${ }^{7}$ Brem v. Eisner, 746 A.2d 244, 262-64 (Del. 2000).
} 
decision may have a 'long-term' benefit, ${ }^{8}$ however abstract or unarticulated this benefit may be so long as there is no evidence of bad faith against the corporation. Injury to and bad faith against the corporation are not coterminous. For example, a corporate gift and provision of public aid, being transactions without consideration, financially injure the corporation, and yet such actions are clearly permitted. Courts routinely invoke the Potemkin explanation of a 'long-term' corporate benefit to shield business judgments from active judicial scrutiny of merit even when it appears they have injured the corporation. This is not a judicial wink and a nod to managers who are pursuing some illicit goal, though one must add that with such deference managers sometimes do follow illicit goals as courts abide by a restricted standard of liability. Instead, the Potemkin explanation is really an acknowledgment that the road to a successful corporate enterprise can take many routes. One such route is the incorporation of robust principles of corporate social responsibility into the corporate mission. Would any court admonish the rejection child labour even though its use may prove to be highly profitable? Would any court admonish the use of corporate resources to actively fight child labour as IKEA did? ${ }^{9}$ Another example, a board's decision to assume enormous financial loss by voluntarily rescuing another firm during the financial crisis may be valid on the ground that the long-term interest of a stable financial market is in the best interest of the corporation and shareholders. Much of the legitimacy of corporate law, which gives managers great authority over corporate assets, depends on plausible good faith that precludes substantive review of the board's decision.

An important caveat must be noted. The decision rationale should not be explicitly stated as the pure benefit of a third-party or the social good in a situation where such benefit is not specifically authorized. In other words, the nexus between the long-term benefit of the corporation and the board decision must not be broken with an explicit avowal to the contrary or a disavowal of any desire to advance the interest of the corporation. In Dodge v. Ford, Henry Ford testified that 'the Ford Motor Company has made too much money, has had too large profits, and that, although large profits might be still earned, a sharing of them with the public, by reducing the price of the output of the company, ought to be undertaken. ${ }^{10}$ The Michigan Supreme Court rebuked Ford and ruled against his company with respect to the decision to withhold dividends from the

${ }^{8}$ See, e.g., Shlensky v. Wrigley, 237 N.E.2d 776, 780 (Ill. App. Ct. 1968); Paramount Communications, Inc. v. Time, Inc., 571 A.2d 1140, 1151-55 (Del. 1989); Katz v. Oak Indus., 508 A.2d 873, 879 (Del. Ch. 1986).

${ }^{9}$ Bartlett, C.A, Dessain, V., and Sjdman, A. (14 Nov. 2006), 'IKEA's Global Sourcing Challenge: Indian Rugs and Child Labor (B)', Harvard Business School.

${ }^{10} 170$ N.W. 668, 683-84 (Mich. 1919). 
company's minority shareholders. In so doing, the court added the famous passage that a 'business corporation is organized and carried on primarily for the profit of the stockholders. The powers of the directors are to be employed for that end. ${ }^{11}$

Since this 1919 Michigan case, few jurisdictions have adopted an unconditional rule of shareholder primacy. Outside of the context of a cash buyout of a target in the takeover context where the board is required to maximize shareholder profit, ${ }^{12}$ Delaware courts have eschewed a legal requirement to maximize shareholder profit in favor of manager's prerogative to set the corporate agenda, which may include principles of corporate social responsibility, with the understanding that market forces will influence that agenda significantly. The Delaware Supreme Court has gone so far as to state that a board "is not under any per se duty to maximize shareholder value." 13 The unique aspect of Dodge $v$. Ford is that Ford explicitly rejected the nexus between profit and his purported social ambition. Whether Ford believed this or it was a part of an ill-advised litigation strategy, he chose this black-and-white characterization. In truth, the two ends were closely linked. It is well known now that Ford's social initiative was tied to his production process, which resulted in increased profit, productivity, labor wage, and enhanced social welfare. ${ }^{14}$ Few situations are as stark as Ford seemed to portray. Corporate social responsibility is often positively correlated to profit and enterprise sustainability. Moreover, the author has previously argued that the board can and should reject profit when it believes that a reasonable shareholder would do so given full information as to the choice of profit and moral imperative. Since soliciting actual shareholder preferences is infeasible, managers should abide by what they guess a reasonable shareholder would prefer in a morally complex situation. ${ }^{15}$ Profit maximization may be a default principle, but it is always conditional. Again, under American corporate law, moral deliberation and resulting corporate action are the manager's prerogative. To the extent that Dodge v. Ford has doctrinal authority beyond its unique facts, the lesson is this: if the board's decision is informed and in good faith, and the decision appears to have some nexus to a corporate benefit, however abstract or unformulated it may be, the probability of judicial scrutiny is minimized.

\footnotetext{
${ }^{11}$ Ibid at 684.

${ }^{12}$ Revlon, Inc. v. MacAndrews \& Forbes Holdings, Inc., 506 A.2d 173, 182 (Del. 1986).

${ }^{13}$ Paramount Commc'ns, Inc. v. Time, Inc., 571 A.2d 1140, 1150 (Del. 1989).

${ }^{14} \mathrm{http}: / / \mathrm{www}$. ford.com/.

${ }^{15}$ Rhee, R.J. (2008), 'Corporate Ethics, Agency, and the Theory of the Firm,' Journal of Business \& Technology Law, Vol. 3, pp. 309-332.
} 
Another caveat is that the decision must meet the standard of rationality. ${ }^{16}$ The board's decision does not constitute waste of corporate assets. A claim of waste will arise only in the rare, unconscionable case when a board irrationally squander or give away corporate assets. ${ }^{17}$ This is a corollary to the business judgment rule, which embodies the concept that the board has the power to manage the corporation. In the context of the provision of public aid, the board cannot endanger the corporation as a going concern. No principle of corporate law can support this end. In all other circumstances, the board's decision to use corporate assets and resources in aid of the government or the public good will be protected by the business judgment rule so long as the board used a reasonable procedural process to make the decision.

In summary, the current framework for determining liability allows a board great discretion to pursue business enterprise in a socially responsible way. This is consistent with the entity theory of the corporation, which is the view that the corporation is an entity distinct from its managers and capital providers. Prominent Delaware jurists have suggested that Delaware law leans toward the entity theory. ${ }^{18}$ Accordingly, corporate entities, like natural persons, can be expected to assume basic social responsibilities. Courts understand that the profit motive and corporate social responsibility of the corporation are not mutually exclusive, and that the board acting on behalf of the corporation may lean toward the latter if there is an irreconcilable conflict. In fact, however, the two ends are more aligned than divergent and the long-term sustainability of the corporate enterprise may depend on how responsible it is. Responsible people tend to do well in our society, irresponsible ones do not, and corporations probably track this trend as well. Misbehavior and shirking social responsibility increase the risk to the going concern.

\section{POWER TO AID GOVERNMENT}

The legal framework based on the business judgment rule would allow a board to provide enormous economic resources during a public crisis. But there remains the possibility of liability if an objecting shareholder can prove that the use of corporate resources had no rational nexus to a corporate objective. A real

\footnotetext{
${ }^{16}$ Sinclair Oil Corp. v. Levien, 280 A.2d 717, 720 (Del. 1971).

${ }^{17}$ In re Walt Disney Co. Derivative Litigation, 906 A.2d 27, 74 (Del. 2006).

${ }^{18}$ Strine, L.E. (2002), 'The Social Responsibility of Boards of Directors and Stockholders in Change of Control Transactions: Is There Any “There” There?', Southern California Law Review, Vol. 79, pp. 1179-1187; Allen, W.T., Jacobs, J.B. and Strine, L.E. (2002), 'The Great Takeover Debate: A Mediation on Bridging the Conceptual Divide', University of Chicago Law Review, 69 Vol., pp. 1067-1100.
} 
possibility of liability for waste or bad faith introduces significant legal uncertainty, which may paralyze the decision-making process during a national crisis, precisely when such paralysis could cause great harm.

Assume that a board intentionally provided large corporate assets where the cost-benefit against the action, net of all short-term and long-term, direct and indirect factors. Deliberate conduct to injure a corporation would normally violate the duty of loyalty. ${ }^{19}$ But the board took this action to avert public harm during a national crisis with the understanding that there would be a net loss, perhaps a large one, to the corporation. The board would have intentionally inflicted financial harm, but would there have been a foul? American corporate law has a mechanism that addresses this problem. In the case of a public crisis, no nexus between the provision of corporate resources and corporate purpose is needed. A board need not disingenuously obfuscate the rationale for a decision to rescue the public under the cover a 'long-term benefit of the corporation and shareholders.'

First of all, the provision of corporate assets to third-parties without any consideration has long been a part of corporate law. Corporate philanthropy is authorized by section 122(9) of the DGCL, which provides that a corporation has the power to "make donations for the public welfare or for charitable, scientific or educational purposes, and in time of war or other national emergency in aid thereof. ${ }^{20}$ Gifts need not be justified by some benefit to the corporation, else it would not be a gift but an economic transaction. For instance, the New York corporation statute makes explicit that gifts can be made 'irrespective of corporate benefit.' ${ }^{21}$ The authority to provide corporate gifts as a part of a broader corporate social responsibility agenda has long been established. For instance, the New Jersey Supreme Court wrote in the well-known case, A.P. Smith Manufacturing Company v. Barlow: 'It seems to us that just as the conditions prevailing when corporations were originally created required that they serve public as well as private interests, modern conditions require that corporations acknowledge and discharge social as well as private responsibilities as members of the communities within which they operate.' ${ }^{22}$ The power to distribute corporate assets free of consideration toward the public welfare in an appropriate and responsible manner is the most direct evidence that corporate law allows

\footnotetext{
${ }^{19}$ Ibid at 67 (" $[\mathrm{W}]$ here the fiduciary intentionally fails to act in the face of a known duty to act, demonstrating a conscious disregard for his duties ....').

${ }^{20}$ Del. Code Ann. tit. $8 \S 122(9)$. See Model Bus. Corp. Act $\S 3.02(13)$ (corporation has the power 'to make donations for the public welfare or for charitable, scientific, or educational purposes') and $\S 3.02(15)$ (corporation has the power 'to make payments or donations, or do any other act, not inconsistent with law, that furthers the business and affairs of the corporation').

${ }^{21}$ N.Y Bus. Corp. Law § 202(12) (McKinney 2009).

${ }^{22}$ A.P. Smith Mfg. Co. v. Barlow, 98 A.2d 581, 586 (N.J. 1953) .
} 
managers broad discretion to incorporate principles of corporate social responsibility in the management of the firm.

There is also a specific statute addressing the board's authority to provide resources in furtherance of the social good during a public crisis. Section 122(12) of the DGCL empowers a corporation to 'transact any lawful business which the corporation's board of directors shall find to be in aid of government authority. ${ }^{, 2}$ Surprisingly, no Delaware court has cited or analyzed section 122(12) and scholarly attention has been scant, presumably because the circumstance required to invoke this power would be most unusual.

This provision is a broad grant of authority. The board has the authority to 'transact any lawful business ... in aid of government authority.' The dictionary definition of aid is 'help given ... tangible means of assistance (as money or supplies). ${ }^{24}$ The historical definition is a 'subsidy or tax granted to the king for an extraordinary purpose' as well as a 'benevolence or tribute (i.e., a sum of money) granted by the tenant to his lord in times of difficulty and distress.' ${ }^{25}$ This etymology is obviously meaningful.

The Bank of America-Merrill Lynch episode shows the potential utility of section 122(12). Even if Bank of America had the option to terminate the transaction, the board should not be held liable for choosing to assume Merrill Lynch's $\$ 15$ billion loss, as long as it did so to aid government and rescue the public welfare. The statute has application beyond the financial crisis since crises are a part of the human condition. Consider the following hypothetical. There is a full-blown global pandemic, and a pharmaceutical company has the only treatment for this particular disease. In light of a global pandemic, the board decides to sell the treatment at cost to wealthy countries and give it away to poorer countries at a direct cost. Can the board sacrifice an enormous profit opportunity by coming to the aid of government and society? Boards are authorized to do so under American corporate law so long as the action was done so advisedly and it does not impair the corporation as a going concern. Any question of waste would be dispelled by a powerful cocktail of the business judgment rule and the evocation of the 'long-term' benefit to the corporation and shareholders to be gotten the goodwill gesture.

\section{FIDUCIARY EXEMPTION}

\footnotetext{
${ }^{23}$ Del. Code ann. tit. 8 § 122(12) (2009). See Model Bus. Corp. Act $\S 3.02(14)$ (containing a similar provision: '[T]o transact any lawful business that will aid governmental policy.').

${ }^{24}$ (9th ed. 1985), Webster's Ninth New Collegiate Dictionary, G. \& C. Merriam Co., Springfield, MA.

${ }^{25}$ Garner, B.A. (9th ed. 2009), Black's Law Dictionary, West Group, St. Paul, MN.
} 
The board has the authority, but there remains the question: Is such authority bound by a legal limit? Since no court has spoken on section 122(12) or similar provisions found in other state statutes, this question remains open. In this subsection, an argument for unbounded authority is advanced.

The plain text of the statute suggests the boundary is very broad at least. Since the government is the primary beneficiary, one may infer that the legislature intended to grant the board great discretion in providing private aid to a public cause. Delaware courts could import into section 122(12) a limit based on some formulation of the rationality standard. If there is to be limiting principle, such principle should be the foundation of the business judgment rule, specifically an appropriate ex ante procedure leading to an informed, good faith decision with the limit of rationality as the outer boundary. During a national crisis, the limit of rationality would be the point at which the board's decision could be said ex ante to have financially endangered or impaired the corporation as a going concern. Corporate endangerment, self-mutilation or suicide is not an aspirational end of corporate law. The risk of such event occurring is sufficiently great from the acts of the unfortunate, negligent or corrupt manager, and the law need not add to this burden. Therefore, a reasonable limiting principle may be that the board would be irrational when it takes action knowing ex ante that its action would impair the corporation's long-term financial health as a going concern.

However, there are countervailing considerations. A legal limit would be problematic. The waste standard could be inadequate during a public crisis, which is always some large, exigent social problem. The standard must be malleable to the circumstances. The standard applicable to corporate gifts to hospitals or museums may be meaningless in the context of a public crisis. Recall that Bank of America assumed Merrill Lynch's \$15 billion fourth-quarter loss; this loss may be so breathtaking that it constitutes clear waste from the standpoint of an ordinary corporate gift. One expects that any meaningful aid during a public crisis may be substantial, thus automatically creating a potential legal liability for the board if the provision of resources are commensurate with the enormity of the stake involved. There is a potential Catch-22 absurdity: the exigency of the situation creates a real legal risk when a board exercises the very authority granted by statute.

The existence of legal risk suggests that the board's authority should be absolute, and not qualified even under the lenient standard of rationality, which would always open the door to the possibility of liability. Although there is a strong argument for a limiting principle, an argument is advanced here that there should be a fiduciary exemption when a board acts under section 122(12) to 'aid of government authority' or when it otherwise provides aid in response to a public crisis. A fiduciary safe-harbour is better because it removes legal risk from the board's decision involving a public necessity. 
The experiences in tort law and public catastrophes have shown that the paralyzing effect of litigation risk is real during a public crisis and can lead to very poor outcomes. The Pennsylvania Supreme Court's reflection on history is informative: 'We find, indeed, a memorable instance of folly recorded in the 3 Vol. of Clarendon's History, where it is mentioned that the Lord Mayor of London, in 1666, when that city was on fire, would not give directions for, or content to, the pulling down forty wooden houses ... for fear he should be answerable for a trespass; and in consequence of this conduct half that great city was burnt.' ${ }^{26}$ A small probability of liability would not be reassuring for a board. Public crises may require consequential decisions with large sums of resources at stake. A low probability, high magnitude liability payout may still result in a significant expected value of the legal risk. Exposure to such litigation risk may be sufficiently high to deter potentially beneficial motive and action.

Authority without legal limit, which is another way to view a fiduciary safe-harbour, would be novel. The basic assumption bears repeating that the costbenefit of providing aid during a public crisis would be clear. No legal limit on authority is not equivalent to no limitation at all. First of all, few boards are irrational, and fewer boards still have been found to have acted irrationally with corporate assets. Because the rationality standard is so lenient, it does not result in much liability; but the threat of liability may pose a real risk of hesitation and inaction at a time when such a response can prove to be most unhelpful. Also, self-preservation is a powerful instinct even when a board is acting as an agent for the legal entity. The moral sentiment of a good Samaritan is limited by the perceived economic and moral obligations to the various constituents of the corporation, including shareholders, creditors, employees, and communities. Board members are also bound by their own reputational interests, and a good deed at a ruinous cost to the corporation would not assure a board member's reputation or standing in the corporate ballot box. The instinct for selfpreservation and self-interest are powerful constraints on a desire to provide overly generous provision of aid to the impairment of the corporate enterprise.

Moreover, the circumstances of a crisis provide the necessary constraint. Just because there is a public crisis, corporate boards would not be lining up to provide large resources in amounts that would trigger the threat of litigation. The situational context dictates that for a firm to consider a rescue at all, it would have to be uniquely situated in relation to the crisis. One would not expect Pfizer to rescue financial institutions during a crisis in the financial markets, and likewise we would not expect JPMorgan Chase to rescue the public during a global pandemic. A direct causality would connect corporate munificence. The

\footnotetext{
${ }^{26}$ Respublica v. Sparhawk, 1 Dall. 357, 362 (Pa. 1788).
} 
uniqueness of a firm's situation in relation to the public crisis provides a natural, extra-legal constraint on board action.

There is also a pragmatic political reason for fiduciary exemption. In the American scheme, the primary threat to state control of corporate law is federal preemption of the field, which is constitutionally permissible. States, and particularly Delaware, are always wary of this potential of federal intervention into their corporation laws. If state corporate law undermined federal policy by deterring corporate cooperation with government policy or punishing corporate boards with liability for providing public aid when the dust settles, there would be a real risk of federal preemption of corporate law or some aspects of it. States would not want this result. Corporate law is primarily state law only upon the implicit approval of the federal government.

Based on the above reasons, a rule of fiduciary exemption is more sensible. The proposed rule is simply stated: upon a public necessity, a board of a firm that is uniquely situated to avert or mitigate a public crisis is exempt from its ordinary fiduciary duty to the corporation insofar as it distributes corporate assets with the intent to aid the government or the public.

\section{PUBLIC NECESSITY AND COST-BENEFIT}

The theoretical justification for fiduciary exemption can be found in a well established doctrine of tort law dealing with public crisis and necessity. Corporate law borrows much of its concepts of duty and standard of liability from tort law. The analogy to tort law is a natural one. The most obvious application of tort law principles is a director's duty of care, which defined in terms of a cause of action for negligence. The tort analogy does not stop at the concept of negligence. The duty of loyalty resembles the concept of an intentional tort. Theft of corporate assets is a breach of the duty of loyalty, as is bad faith conduct resulting in harm to the corporation. ${ }^{27}$ The influence of tort law is seen even in the realm of takeover law. The law of self-defense informs Delaware's standard for reviewing the appropriateness of a board's adoption of antitakeover defenses. Under Unocal Corp. v. Mesa Petroleum, the target has the burden to establish that the board reasonably perceived that the hostile takeover bid was a threat to the corporation, and the takeover defensive measure adopted was reasonable in response to the threat. ${ }^{28}$ This standard is analogous to the tort standard, which provides that selfdefense measures cannot be 'in excess of that which the actor correctly or reasonably believes to be necessary for his protection. ${ }^{29}$

\footnotetext{
${ }^{27}$ Stone v. Ritter, 911 A.2d 362, 370 (Del. 2006).

${ }^{28} 493$ A.2d 946, 954-55 (Del. 1985).

${ }^{29}$ Restatement (Second) of Torts § 70(1) (1965).
} 
Tort law informs the liability scheme of corporate law as the two bodies of law fundamentally concern wrongful conduct and liability there from, though obviously applications and policies may differ, perhaps substantially so, in the details of the liability scheme. Tort law proves useful in analyzing a board's liability for financial harm arising from a private sacrifice of corporate profit or assets. Specifically, the tort doctrine of public necessity provides a theoretical justification for fiduciary exemption.

In tort law, public necessity creates a complete defense against an intentional tort to property. A public necessity is a situation when there is a broader threat to the public wealth or welfare. The common law has long recognized this defense, which dates back as far as 1609 to Mouse's Case, ${ }^{30}$ and it states that an actor who harms the property of another in response to a public emergency is not liable to the property owner. The efficiency consideration of public necessity is apparent: the cost-benefit analysis always weighs in favor of preserving the public welfare or wealth over private property. This rule clearly satisfies the cost-benefit criterion. Nevertheless, the question is: why not impose the imperfect privilege and require compensation? The simple answer is that the cost-benefit always works in favor of mitigating a public crisis and the risk is too great from the moment's hesitation by an actor who is in a position to rescue based on the calculation of the risk of liability.

The thesis advanced here is consistent with the animating principle of corporate law - that is, corporate law is founded on the principle of social wealth maximization. This principle is not the same as shareholder profit maximization, which at its essential level is a distributive concern. Shareholder primacy is a default norm only, and it can be subjugated to the interests of other constituents. Many states have constituency statutes that permit the board to consider the stakeholder interests. Shareholder primacy is subjugated to the specific power of the board to provide both gifts and government aid under sections 122(9) and 122(12).

Shareholder primacy is based on efficiency consideration, but maximizing profit is not ipso facto a superior proposition. The proposition fails, for example, when the shareholders' claim is viewed as an out-of-the-money call option, as is the case in insolvency. Intrinsic in the concept is a distributive quality. Stated simply, it is fairly obvious that shareholder wealth can increase in only three distinct ways: (1) the total size of the wealth created by the enterprise increases, thus leaving a greater residual claim for the shareholders; (2) the economic pie remains the same, but shareholders take a greater portion than other claimants;

\footnotetext{
${ }^{30}$ (1609) 77 Eng. Rep. 1341 (K.B.) (holding that 'it is lawful for any passenger to cast the things out of the barge [upon a sudden storm] . . . everyone ought to bear his loss for the safeguard and life of a man').
} 
and (3) shareholders increase their wealth by taking action that reduces the size to the economic pie, thus diminishing the aggregate returns to other claimants.

Only the first proposition increases social wealth and is thus a normatively superior outcome. The second proposition is neutral as to social wealth, and the matter concerns only the equity of distribution. In these circumstances, the law generally does not interfere in the contractual relationships establishing the distribution of the economic pie. It is said that enterprise law provides a set of default contract terms among factors of production. Absent fraud or some other bad motive, the contract terms govern and market forces primarily provide the pricing mechanism for these commercial relationships, including the market for corporate control if the shareholder slice is less than it should be. The third proposition is a clearly inferior proposition. The notion that shareholders are made wealthy by reducing the social wealth cannot be a desired goal. To be sure, this effect is seen, perhaps frequently, as is the case when limited liability is used as an ex ante liability avoidance scheme. Would any efficient or just society provide a shield against liability if it had perfect information and knew beforehand that a firm would impart social cost for which its assets cannot pay? Such a society would be economically and morally bankrupt. A rule promoting a reduction in the aggregate social wealth is inefficient and can be justified only on the illicit premise that a specific class of capital providers has an inalienable entitlement to their wealth maximization.

The criterion used to determine corporate law's efficiency is important. Efficiency is based on the Kaldor-Hicks criterion, which is distinguished from the Pareto superior efficiency. The Pareto superior criterion states that a change is efficient if at least one person is made better off and no person is made worse off. This criterion has few practical applications because transactions often have thirdparty effects and the cost of bringing about compensation may often exceed the net surplus. Kaldor-Hicks efficiency provides that a change is efficient if gainers gain more than the losers lose. The important concept is that in principle the gainers could compensate the losers and still enjoy a surplus, but compensation is not required. This is essentially a cost-benefit analysis.

A cost-benefit analysis is the governing principle of corporate law. Society has a normative preference for greater aggregate wealth and welfare. The distributive principle of shareholder primacy is not the end of corporate law, but is instead a default setting because in most cases profit maximization nicely correlates to increased social wealth and welfare. The default setting can change when the social cost-benefit calculus changes. In the face of clear evidence of the threat of abnormally large social harm associated with a national crisis, the board can subjugate shareholder primacy, which even in normal times is an unenforceable norm, to directly advance the societal interest preventing or mitigating such harm. 
The financial crisis of 2008 teaches that the cost-benefit analysis does not always weigh in favor of private financial gain. Much of its causality can be explained by the pursuit of short-term private gain by employees, managers, and vicariously passive shareholders of the many firms responsible for the crisis. In ordinary circumstances, the framing of shareholder primacy is not at issue, and we correctly assume that the profit-maximizing firm with its embedded distributive principle generally tends to enhance social wealth and welfare because the legal process is ill-suited to engage in an individualized assessment of the cost-benefit and distribution of surplus to the various participants and constituents. The rising tide of shareholder wealth lifts all boats, it is correctly assumed as the default aspiration. The incentive structure underlying profit maximization works most of the time in ordinary circumstances. This default setting, however, should not diminish society's greater interest in the protection of the financial markets and the national economy, or the public good more generally in time of great crises. These interests can outweigh the narrow financial interests of any single firm since a sound economy and market are preconditions to the long-term health of the company.

While Delaware law cannot mandate the pursuit of the public welfare, just as it cannot mandate shareholder profit maximization, without encroaching on the board's prerogative to manage the corporation, it leaves the board with great leeway to do precisely that. The business judgment rule protects board action within the bounds of rationality, and the board can rely on such half-fictional, abstractized reasoning as pursuing the 'long-term' interest of the corporation and shareholders. Additionally, Delaware law provides broad flexibility in terms of the provision of corporate assets in times of national crisis through sections 122(9) and 122(12) of the DGCL. In crisis, fiduciary duty and board authority are elastic concepts sufficient to encompass the promotion of the public welfare as the primary objective of action.

The Bank of America-Merrill Lynch episode is instructive. Bank of America's board had many things to consider before determining whether to complete the merger with Merrill Lynch, including the potential harm to the financial markets and the public welfare in time of great crisis. This is no small consideration, and a systemically-important financial institution should have important obligations toward the soundness of the financial system. Moreover, shareholder primacy has little role in the government's policy decision making. Even when the government is an investor in a bailout, it is myopic to believe that such public funds are deployed for the primary benefit of the shareholders in the firm. Any benefit to shareholders from government action was incidental toward the larger goal of stabilizing a collapsing economy. In a crisis, larger issues can be at stake than the wealth of shareholders. The board of a financial institution could also legitimately take a similar view. A board would have been well within its 
authority to consider the public welfare as the primary, albeit temporary, end of corporate action.

\section{CONCLUSIONS}

While not perfect, American corporate law is ingenious in the flexibility it provides managers. Intrinsic in the business judgment rule is a judicial recognition that managing a complex economic organization in an even more complex economy is quite challenging. A corporation operates not in the abstract vacuum of a nexus of contracts among its factors of production, but in the greater web of social and political relationships to which that nexus forms a vital part. Under Delaware law, at least, a corporation is an entity distinct from its capital providers and managers. This suggests that the corporation as served by the board has social responsibilities it should meet while conducting its business and affairs. These obligations, like the obligation to achieve profit, cannot be legally mandated, but are instead mandated by moral and economic duties to various constituents and factors of production. Establishing the judicial decision standard for either goal is illusory. Instead, the board has the discretion to calibrate this balance, including the deliberation of the ethics of the action and principles of corporate social responsibility.

No situation calls for sensitivity to corporate social responsibility more than when a public crisis strikes. The stakes are the greatest. In time of crisis, corporate activity can take the form of public-private activity, or at least it can impart significantly greater effects on social wealth and public welfare. American corporate law is flexible enough to provide for this contingency. The combination of the business judgment rule and section 122(12)-together, embodying the principle that managers shall have the authority to manage the corporationprovides the board with sufficient authority to act in the interest of the public welfare at the sacrifice of corporate resources. However, there still remains a real possibility of legal liability, simply because the amount of any meaningful resources in a rescue can be extraordinary. No American court has ruled on this issue. This ambiguity in the liability scheme is problematic.

In these situations, the normal rules do not apply. There should be a fiduciary safe-harbour where a board acts in the public interest during a public crisis. Given an unavoidable Hobson's choice, it would be inefficient to uphold a norm or legal rule requiring a board to pursue private economic gain at a tremendous direct cost to society when a board can avoid such cost through the provision of aid. A norm or legal rule that jeopardizes or deters a voluntary rescue would also be morally suspect. If the cost-benefit analysis on a broader level is obvious, a board should be allowed to provide aid to the public without legal risk overhanging its decision. 
The animating principle of corporate law is the maximization of social wealth and welfare, and not the more narrow interest of shareholder profit, which is essentially a distributive principle. In time of crisis, the benefit to the public may be so large and obvious that the presumptive social benefit of shareholder primacy is clearly rebutted by the potential harm. The cost-benefit analysis may permit a primary obligation to consider the public good. Despite the sometimes ideological nature of the defense of shareholder primacy, corporate decision making is much more complex than can be served by unconditional, bright-line rules or canons of economic or political philosophy. A board should be allowed to act explicitly on behalf of the public good without resort to such disingenuous elision as the 'long-term interest of the corporation and shareholders.' Such honesty recognizes that the corporate enterprise is integrated into the fabric of society rather than a separate, discrete nexus of contracts removed from the surrounding context and designed solely to maximize value for shareholders as residual claimants. The financial crisis of 2008 will not be the only national crisis. When crises strike, the public welfare should not be sacrificed upon the altar of shareholder primacy. Faith therein has its limits. 